\title{
Length-weight and length-length relationships of chub (Squalius cephalus, L., 1758) inhabiting a few inland waters of the Middle Black Sea Region
}

\section{Orta Karadeniz Bölgesi'ndeki bazı akarsularda yaşayan tatlısu kefali (Squalius cephalus, L.1758)'nin boy-ağırlık ve boy-boy ilişkileri}

\author{
Melek Özpiçak* (D) • Semra Saygın (D) - Enes Hançer (D) • Aykut Aydın (D) • \\ Savaş Yılmaz (D) Nazmi Polat
}

Ondokuz Mayis University, Faculty of Art and Sciences, Biology Department, 55139, Samsun, Turkey

*Corresponding author: melek.zengin@omu.edu.tr

How to cite this paper:

Özpiçak, M., Saygın, S., Hançer, E., Aydın, A., Y.lmaz, S. \& Polat, N. (2018). Length-weight and length-length relationships of chub (Squalius cephalus, L., 1758) inhabiting a few inland waters of the Middle Black Sea Region. Ege Journal Fisheries and Aquatic Sciences, 35(2), 175-179. DOI:10.12714/egejfas.2018.35.2.10

\begin{abstract}
In this study, the length-weight and length-length relationships of chub (Squalius cephalus, L.1758) sampled from a few inland waters of the middle Black Sea were investigated. A total of 218 (Abdal $(\mathrm{N}=44)$, Akçay ( $\mathrm{N}=57)$, Terme $(\mathrm{N}=55)$, Yedikı $(\mathrm{N}=62)$ ) chub individuals were sampled from different localities. All captured individuals were measured to the nearest $0.1 \mathrm{~cm}$ for total, fork and standard lengths. The weight of each sample (W) was recorded $(0.01 \mathrm{~g})$. According to results of analyses, there were no statistically significant differences between sexes in terms of length and weight $(P>0.05)$. So, entire populations (female+male) were evaluated together for analyses. The average total lengths of chub sampled from the Abdal Stream, Akçay Stream, Terme Stream and Yedikir Dam Lake varies between $11.49 \pm 0.792,10.31 \pm 0.518,10.33 \pm 0.289$ and $11.11 \pm 0.327 \mathrm{~cm}$, respectively. The length-weight relationships (LWRs) were found highly significant $\left(P<0.001, r^{2}>0.990\right)$ for all localities. The value of ' $b$ ' of $L W R$ was significantly different from 3.0 in chub and the growth type is possitive allometric for all localities. The equations of length-weight relationship were calculated as $W=0.007 \mathrm{TL}^{3.224}, \mathrm{~W}=0.006 \mathrm{TL}^{3.285}, \mathrm{~W}=0.005 \mathrm{LL}^{3.228}, \mathrm{~W}=0.007 \mathrm{TL}^{3.210}$ for Abdal, Akçay, Terme and Yedikır, respectively. Length-length relationship was also highly significant $(P<0.001)$ with coefficient of determination $\left(r^{2}\right)$ ranging from 0.916 to 0.999 .
\end{abstract}

Keywords: Chub, length-weight relationship, length-length relationship, Black Sea, Turkey

Öz: Bu çalışmada orta Karadeniz Bölgesi'ndeki bazı içsularda yaşayan tatıısu kefalinin (Squalius cephalus, L.1758) boy-ağıllık ve boy-boy ilişkileri incelenmiştir. Toplamda 218 (Abdal $(\mathrm{N}=44)$, Akçay ( $\mathrm{N}=57)$, Terme $(\mathrm{N}=55)$, Yedikır $(\mathrm{N}=62)$ ) örnek farkı lokalitelerden örneklenmiştir. Yakalanan tüm örneklerin total, çatal ve standart boyları $(0.1 \mathrm{~cm})$ ölçülmüştür. Her bir örneğin ağırlığı $(W)$ kaydedilmiştir $(0.01 \mathrm{~g})$. Analiz sonuçlarına göre cinsiyetler arasında boy ve ağırlık bakımından istatistiksel olarak önemli bir farkllık yoktur ( $P>0.05$ ). Bu sebeple tüm populasyon (dişi+erkek) analizlerde birlikte değerlendirilmiştir. Abdal Çayı, Akçay Çayı, Terme Çayı ve Yedikır Baraj Gölü'nden örneklenen tatısu kefalinin ortalama total boyları sırasılla $11.49 \pm 0.792,10.31 \pm 0.518,10.33 \pm 0.289$ ve $11.11 \pm 0.327 \mathrm{~cm}$ arasında değişmektedir. Boy-ağırlık ilişkileri tüm lokaliteler için önemli bulunmuştur $\left(P<0.001, r^{2}>0.990\right)$. Boy-ağıllık ilişkisinin "b" değeri istatistiksel anlamda 3'ten fakııdır ve tüm lokaliteler için büyüme tipi pozitif allometriktir. Boy-ağırlık ilişkilerinin denklemleri sırası ile Abdal, Akçay, Terme ve Yedikır için W=0.007TL3.224, $\mathrm{W}=0.006 \mathrm{TL}^{3.285}, \mathrm{~W}=0.005 \mathrm{TL} \mathrm{L}^{3.298}, \mathrm{~W}=0.007 \mathrm{TL}^{3.210}$ olarak hesaplanmıştır. Boy-boy ilişkilerinin regresyon katsayıları 0.916 ile 0.999 arasında değişim göstermektedir ve istatistiksel anlamda önemlidir $(\mathrm{P}<0.001)$.

Anahtar kelimeler: Tatısu kefali, boy-ağırlık ilişkisi, boy-boy ilişkisi, Karadeniz, Türkiye

\section{INTRODUCTION}

Squalius cephalus (chub) (L., 1758) is a freshwater fish species widely distrubuted all around the world. The chub is widespread in the whole of Europe, the Black Sea, the Azov Sea, the Caspian Sea, and most of the inland waters in Anatolia. This fish species is economically important and there are lots of studies about genetic, biological characteristic, population parameters and systematics of chub from different localities (Laroche et al., 1999; Arlinghaus and Wolter, 2003; Turan et al., 2007; Dehais et al., 2010; Bulut et al., 2012; Cejko and Krejszeff, 2016; Gouskov, 2016; Özcan et al., 2017). The conservation status of chub is "LC" according to IUCN (The IUCN Red List of Threatened Species, Version 2017-3).

Length-weight (LWRs) and length-length relationships (LLRs) are very important for fisheries researches. Lengthweight-related parameters provide predicting the weight of the fish from its length and life cycle of the populations from different habitats. Also, LWRs allow the transformations of growth-in-length equations to growth in-weight, for use in stock 
assessment models; an estimate of the condition of fish; useful for region comparisons of life histories of fish species (Petrakis and Stergiou, 1995; Gonçalves et al., 1997; Binohlan and Pauly, 1998). LLRs are important in comparing growth studies using different length types for fisheries management (Moutopoulos and Stregiou, 2002).

In fisheries biology, LWRs and LLRs are base studies and allow for comparisons of species growth between different regions. Therefore, these studies are also prefered for stock analyses. In this study, we aimed to determine the LWRs and LLRs of chub which sampled from the four different localities (Abdal Stream, Akçay Stream, Terme Stream and Yedikır Dam Lake) along inland waters of the Middle Black Sea Region.

\section{MATERIALS AND METHODS}

\section{Sampling}

Chub samples obtained from Abdal Stream $(N=44)$, Akçay Stream $(\mathrm{N}=57)$, Terme Stream $(\mathrm{N}=55)$ and Yedikır Dam Lake $(\mathrm{N}=62)$. The coordinates of sampling locations and date were recorded using GARMIN GPS (Table 1-Figure 1). Samples were collected with SAMUS 725 MP electroshocker.

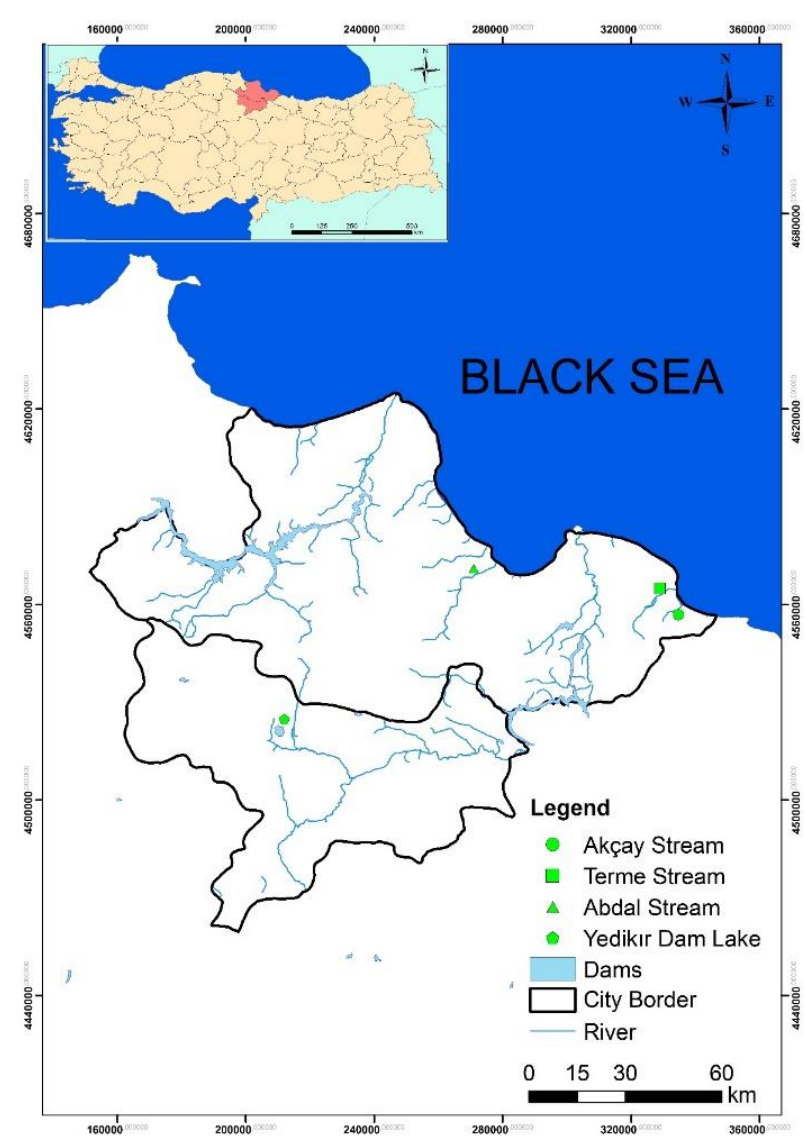

Figure 1. Sampling area
Table 1. Coordinates of sampling localities

\begin{tabular}{|c|c|c|c|}
\hline Locality & Sampling Date & Coordinates & $\mathbf{N}$ \\
\hline $\begin{array}{l}\text { Abdal } \\
\text { Stream }\end{array}$ & April 2017 & $\begin{array}{l}41^{\circ} 09^{\prime} 22.38 \text { "N } \\
36^{\circ} 44^{\prime} 21.54^{\prime \prime} \mathrm{E}\end{array}$ & 44 \\
\hline $\begin{array}{l}\text { Akçay } \\
\text { Stream }\end{array}$ & October 2015 & $\begin{array}{l}41^{\circ} 05^{\prime} 30.99 \text { "N } \\
37^{\circ} 07^{\prime} 20.89^{\prime \prime} \mathrm{E}\end{array}$ & 57 \\
\hline $\begin{array}{l}\text { Terme } \\
\text { Stream }\end{array}$ & February 2016 & $\begin{array}{l}41^{\circ} 09^{\prime} 34.03 \text { "N } \\
36^{\circ} 53^{\prime} 28.48^{\prime \prime} \mathrm{E}\end{array}$ & 55 \\
\hline $\begin{array}{l}\text { Yedikır Dam } \\
\text { Lake }\end{array}$ & July 2016 & $\begin{array}{l}40^{\circ} 47.5^{\prime} 5.38 \text { "N } \\
35^{\circ} 33^{\prime} 10.16^{\prime \prime} \mathrm{E}\end{array}$ & 62 \\
\hline
\end{tabular}

\section{Biological studies and statistical analysis}

Fish samples were measured for total length (TL), fork length (FL) and standard length $(\mathrm{SL})(0.1 \mathrm{~cm}$.) The weight of each fish $(\mathrm{W})$ was recorded $(0.01 \mathrm{~g})$. Sex was determined by macroscopic examination of the gonads.

Length-weight relations were calculated using the equation $\mathrm{W}=a \mathrm{~L}^{\mathrm{b}}$, where $\mathrm{W}$ is the total weight of the fish $(\mathrm{g}), \mathrm{L}$ is the total length $(\mathrm{cm}), a$ and $b$ are the parameters of the equation (Bagenal and Tesch, 1978). The t-test employed to test whether the slopes (b) were significantly different from 3 , indicating the growth type: isometric $(b=3)$, positive allometric $(b>3)$ or negative allometric $(b<3)$. Analysis of variance (ANOVA) was used to test differences of the $b$ values of lengthweight relationship between sexes (Zar, 1999).

All length-length relationships of chub samples were computed using linear regression analysis (Zar, 1999). Relationships between TL \& FL, FL \& SL, and SL \& TL were estimated separately according to all localities.

Statistical analyses were tested by at the 0.05 significance level. SPSS 20, Minitab 15.0 and the Excel software were utilized in the evaluation of data.

\section{RESULTS}

The average total length of the individuals sampled from the Abdal Stream, Akçay, Terme and Yedikır Dam Lake varies between $11.49 \pm 0.792, \quad 10.31 \pm 0.518, \quad 10.33 \pm 0.289$ and $11.11 \pm 0.327 \mathrm{~cm}$. The descriptive statistics of chub samples from four locality indicated in Table 2. There are no differences in terms of $\mathrm{TL}$ or $\mathrm{W}$ between localities according to sex $(P>0.05)$. So, entire populations (female+male) were evaluated together for analyses.

LWRs were calculated for all localities. The LWRs were significantly important $\left(P<0.001, r^{2}>0.990\right.$, Table 3$)$. The value of ' $b$ ' of LWR was found to be significantly different from 3.0 in chub and the growth type were possitive allometric for all localities according to results of this study (Table 3 ). 
Table 2. Descriptive statistics of $S$. cephalus samples from different localities

\begin{tabular}{lccccccc}
\hline Locality & $\begin{array}{l}\text { Parameters } \\
\text { TL }(\mathbf{c m}) / \mathbf{~ W} \text { (g) }\end{array}$ & N & Mean & Min. & Max. & SD. & SE. \\
\hline \multirow{2}{*}{ Abdal Stream } & TL & \multirow{2}{*}{44} & 11.49 & 5.60 & 29.40 & 5.255 & 0.792 \\
\multirow{2}{*}{ Akçay Stream } & W & & 33.59 & 1.82 & 328.1 & 64.36 & 9.700 \\
& TL & \multirow{2}{*}{57} & 10.31 & 5.80 & 18.00 & 3.911 & 0.518 \\
Terme Stream & W & & 18.81 & 1.79 & 67.57 & 19.37 & 2.570 \\
& TL & \multirow{2}{*}{55} & 10.33 & 6.40 & 15.60 & 2.146 & 0.289 \\
Yedikır Dam Lake & W & & 13.18 & 2.39 & 46.99 & 8.61 & 1.160 \\
& TL & \multirow{2}{*}{62} & 11.11 & 6.70 & 17.70 & 2.575 & 0.327 \\
& W & & 20.18 & 3.39 & 71.30 & 16.75 & 2.130 \\
\hline
\end{tabular}

TL: total length; W: weight; SD: standard deviation, Min: minimum; Max: maximum; SE: standard error

Table 3. Parameters of the LWR and growth types for S. cephalus according to localities

\begin{tabular}{|c|c|c|c|c|c|}
\hline Locality & a & b & $r^{2}$ & $\begin{array}{c}95 \% \\
\text { Confidence } \\
\text { Interval }\end{array}$ & $\begin{array}{c}\text { Growth } \\
\text { Type }\end{array}$ \\
\hline $\begin{array}{l}\text { Abdal } \\
\text { Stream }\end{array}$ & 0.007 & 3.224 & 0.995 & $3.156-3.292$ & $\begin{array}{c}(+) \\
\text { Allometry }\end{array}$ \\
\hline $\begin{array}{l}\text { Akçay } \\
\text { Stream }\end{array}$ & 0.006 & 3.285 & 0.997 & 3.245-3.356 & $\begin{array}{c}(+) \\
\text { Allometry }\end{array}$ \\
\hline $\begin{array}{l}\text { Terme } \\
\text { Stream }\end{array}$ & 0.005 & 3.298 & 0.993 & 3.194-3.402 & $\begin{array}{c}(+) \\
\text { Allometry }\end{array}$ \\
\hline $\begin{array}{l}\text { Yedikır } \\
\text { Dam Lake }\end{array}$ & 0.007 & 3.210 & 0.992 & 3.104-3.316 & $\begin{array}{c}(+) \\
\text { Allometry }\end{array}$ \\
\hline
\end{tabular}

Table 4. LLRs between TL, FL and SL of chub inhabiting a few inland waters of Middle Black Sea Region of Turkey

\begin{tabular}{clcccc}
\hline Localities & Equations & $\mathbf{a}$ & $\mathbf{b}$ & $\mathbf{r}^{2}$ & $\mathbf{P}$ \\
\hline \multirow{2}{*}{ Abdal } & $\mathrm{TL}=\mathrm{a}+\mathrm{bFL}$ & 0.279 & 1.04 & 0.999 & $<0.001$ \\
Stream & $\mathrm{FL}=\mathrm{a}+\mathrm{bSL}$ & -0.019 & 1.15 & 0.999 & $<0.001$ \\
& $\mathrm{SL}=\mathrm{a}+\mathrm{bTL}$ & -0.201 & 0.84 & 0.999 & $<0.001$ \\
\multirow{4}{*}{ Akçay } & $\mathrm{TL}=\mathrm{a}+\mathrm{bFL}$ & 0.110 & 1.06 & 0.998 & $<0.001$ \\
Stream & $\mathrm{FL}=\mathrm{a}+\mathrm{bSL}$ & 0.929 & 0.99 & 0.922 & $<0.001$ \\
& $\mathrm{SL}=\mathrm{a}+\mathrm{bTL}$ & -0.239 & 0.87 & 0.916 & $<0.001$ \\
Terme & $\mathrm{TL}=\mathrm{a}+\mathrm{bFL}$ & -0.048 & 1.08 & 0.981 & $<0.001$ \\
Stream & $\mathrm{FL}=\mathrm{a}+\mathrm{bSL}$ & 0.297 & 1.09 & 0.985 & $<0.001$ \\
& $\mathrm{SL}=\mathrm{a}+\mathrm{bTL}$ & -0.016 & 0.83 & 0.984 & $<0.001$ \\
Yedikır & $\mathrm{TL}=\mathrm{a}+\mathrm{bFL}$ & 0.267 & 1.03 & 0.991 & $<0.001$ \\
Dam Lake & $\mathrm{FL}=\mathrm{a}+\mathrm{bSL}$ & 0.011 & 1.11 & 0.996 & $<0.001$ \\
& $\mathrm{SL}=\mathrm{a}+\mathrm{bTL}$ & -0.125 & 0.86 & 0.989 & $<0.001$ \\
\hline
\end{tabular}

LLRs were calculated by using the linear regression model. LLRs were also highly significant $(P<0.001)$ with coefficient of determination $\left(\mathrm{r}^{2}\right)$ ranging from 0.916 to 0.999 (Table 4).

\section{DISCUSSION}

The LWRs parameters are extremely important for fish biology and fisheries management (Garcia et al., 1989). Also, length-length associations have a great importance in the comparison of studies using different lengths types (Moutopoulos and Stergiou, 2002; Hossain et al., 2006; Singh and Serajuddin, 2017).
In this study, maximum total lengths of $S$. cephalus were found as $29.40 \mathrm{~cm}$ (Abdal Stream), $18.00 \mathrm{~cm}$ (Akçay Stream), $15.60 \mathrm{~cm}$ (Terme Stream) and $17.70 \mathrm{~cm}$ (Yedikır Dam Lake), respectively. Variations in fish growth in terms of length and weight can be explained as an adaptive response to different ecological conditions (Nikolsky, 1963). Le Cren's concept hypothetically stated that the value of ' $b$ ' in ideal fish to be 3 , indicating an isometric growth, which is widely used as a scale in length-weight relationship study (Singh and Serajuddin, 2017). The values of ' $b$ ' in the present study indicated positive allometric growth for all localities. Many studies have been found when the literature examined about LWR and growth type of S. cephalus (Table 5).

In this study, the growth type of chub was found as possitive allometric. "b" values of Abdal Stream, Akçay Stream, Terme Stream and Yedikır Dam Lake are 3.224, 3.285, 3.298 and 3.210 , respectively. Some factors such as genetic isolation and specific environmental conditions (e.g. temperature, eutrophication levels, food supply and diseases) are responsible for intraspecific differences in growth parameters (Stefanova et al., 2008). Therefore, "b" values of most of the studies could be different from each other between regions.

Length-weight and length-length relationships provides important baseline data to facilitate future fish monitoring and researches. In this study, both LWRs and LLRs were found significantly important $(P<0.001)$. " 2 " values of LWRs were between 0.992 and 0.997 . Various studies indicated that LWRs are very strong in chub (Table 5).

LLRs are also useful for conversion purposes when comparisons are made with literature values, information on growth patterns and consequently to estimate fish biomass (Ault et al., 2005; Aburto-Oropeza et al., 2011). There are different studies used total, fork and standard lengths. This differences causes confusion in some of the studies carried out. At that point, LLRs plays a key role in comparision of studies. Özcan et al. (2017) investigated LLRs of chub from Karasu River and found highly significant relationships $\left(r^{2}>0.95\right.$, $\mathrm{P}<0.001)$. In this study, LLRs were significantly important for all localities $(P<0.001)$ and coefficient of determination $\left(r^{2}\right)$ ranged from 0.916 to 0.999 . 
Table 5. Length-weight relationships of chub from different areas

\begin{tabular}{|c|c|c|c|c|}
\hline Study area & $\mathbf{N}$ & b & Growth Type & Literature \\
\hline $\begin{array}{l}\text { Northern Aegean Eustuarine } \\
\text { (Greece) }\end{array}$ & 627 & 3.856 & $A(+)$ & Kautrakis and Tsigliras (2003) \\
\hline Topçam Dam Lake (Turkey) & 332 & 3.12 & $A(+)$ & Şaşı and Balık (2003) \\
\hline Işıklı Lake (Turkey) & 528 & 3.04 & 1 & Balık et al. (2004) \\
\hline Sir Dam Lake (Turkey) & 422 & $\begin{array}{l}3.214 \text { (for males) } \\
3.174 \text { (for females) }\end{array}$ & $\begin{array}{l}A(+) \\
A(+)\end{array}$ & Kara and Solak (2004) \\
\hline Almus Dam Lake (Turkey) & 305 & 3.359 & $A(+)$ & Karataş and Can (2005) \\
\hline Karakaya Dam Lake (Turkey) & 527 & 2.820 & $A(-)$ & Kalkan et al. (2005) \\
\hline Gelingülü Dam Lake (Turkey) & 267 & 2.870 & I & Kırankaya and Ekmekçi (2007) \\
\hline $\begin{array}{l}\text { İkizcetepeler Dam Lake } \\
\text { (Turkey) }\end{array}$ & 414 & $\begin{array}{l}2.96 \text { (for males) } \\
2.86 \text { (for females) }\end{array}$ & $\begin{array}{l}A(-) \\
A(-)\end{array}$ & Koç et al. (2007) \\
\hline Hafik Lake (Turkey) & 242 & 2.828 & I & Ünver and Kekilli (2010) \\
\hline Çamkoru Pond (Turkey) & 374 & 3.012 & $A(+)$ & İnnal (2010) \\
\hline Tödürge Lake (Turkey) & 466 & 3.088 & I & Ünver and Erk'akan (2012) \\
\hline Gamasiab River (Iran) & 60 & 3.97 & $A(+)$ & Sedaghat et al. (2012) \\
\hline Apa Dam Lake (Turkey) & 474 & 2.43 & $A(-)$ & Mert et al. (2015) \\
\hline Uzunçayır Dam Lake (Turkey) & 334 & 3.136 & $A(+)$ & Demirol et al. (2016) \\
\hline Yeniağa Lake (Turkey) & 729 & 3.109 & $A(+)$ & Kılıç and Becer (2016) \\
\hline Devres Stream (Turkey) & 329 & $\begin{array}{l}2.97 \text { (for males)-3.11 } \\
\text { (for females) }\end{array}$ & - & Benzer and Gül (2017) \\
\hline Karasu Stream (Turkey) & 254 & 3.24 & $A(+)$ & Özcan et al. (2017) \\
\hline $\begin{array}{l}\text { Akçay River (Büyük Menderes } \\
\text { Basin) (Turkey) }\end{array}$ & 366 & $\begin{array}{l}2.72 \text { (for) males) } \\
2.75 \text { (for females) }\end{array}$ & $\begin{array}{l}A(-) \\
A(-)\end{array}$ & Şaşı and Özay (2017) \\
\hline Abdal Stream (Turkey) & 44 & 3.224 & $A(+)$ & This study \\
\hline Akçay Stream (Turkey) & 57 & 3.285 & $A(+)$ & This study \\
\hline Terme Stream (Turkey) & 55 & 3.298 & $A(+)$ & This study \\
\hline Yedikır Dam Lake (Turkey) & 62 & 3.210 & $A(+)$ & This study \\
\hline
\end{tabular}

Length-weight and length-length relationships are important in effective management of fisheries. This is the first study that examined the relationships between total lengthweight and length-length relationships of $S$. cephalus sampled

\section{REFERENCES}

Arlinghaus, R. \& Wolter, C. (2003). Amplitude of ecological potential: chub Leuciscus cephalus (L.) spawning in an artificial lowland canal. Journal of Applied Ichthyology, 19, 52-54. DOI: 10.1046/j.1439-0426.2003.00343.x

Ault, J.S., Smith, S.G. \& Bohnsack, J.A. (2005). Evaluation of average length as an estimator of exploitation status for the Florida coral-reef fish community. ICES Journal of Marine Science. 62, 417-423. DOI: 10.1016/j.icesjms.20 04.12.0 01

Aburto-Oropeza, O., Erisman, B., Galland, G.R., Mascareñas-Osorio, I., Sala E. \& Ezcurra, E. (2011). Large recovery of fish biomass in a no-take Marine Reserve. PLoS One. 6(8). e23601. DOI: 10.1371/journal.pone.0023601

Balık, S., Sarı, M.H., Ustaoğlu, R.M. \& İlhan A. (2004). Age and growth characteristics of chub (Leuciscus cephalus L., 1758) population in Işıklı Lake, Çivril, Denizli, Turkey. Ege Journal of Fisheries and Aquatic Sciences, 21, 257-262. DOI: 10.12714/egejfas.2004.21.3.5000157006

Bagenal, T.B. \& Tesch, F.W. (1978). Age and Growth. In T. Bagenal (Ed), Methods for assessment of fish production in fresh waters, 3rd ed: IBP Handbook No.3, Blackwell Science Publications, Oxford.

Benzer, S. \& Gül, A. (2017). Population structure and some growth properties of chub Squalius cephalus (Linnaeus, 1758) in Devres Stream of Kızılırmak River, Turkey. Journal of Fisheries, 5(3), 513-518. DOI: 10.17017/jish.v5i3.2017.247 from Abdal Steram, Akçay Stream, Terme Stream and Yedikır Dam Lake. The authors hope that this study will support investigators in future for ecological studies and reliable growth estimations.
Binohlan, C. \& Pauly, D. (1998). The length-weight table. In R. Froese and D. Pauly (Ed), Fish Base 1998: Concepts, design and data sources ICLARM, Manila, Philippines. (pp. 121-123).

Bulut, S., Mert, R., Konuk, M., Algan, B., Alap, A. \& Solak, K. (2012). The variation of several biological characteristics of the chub, Squalius cephalus (L., 1758), in the Örenler Dam Lake, Northwest Anatolia, Turkey. Not Scientia Biologica, 4(3), 27-32. DOI: 10.15835/nsb.4.3.7674

Cejko, B.I. \& Krejszeff, S. (2016). Sperm characteristics of chub Leuciscus cephalus (L.) collected in artificial condition after Ovopel and Ovaprim treatment. Aquaculture Research, 47(3), 1-10. DOI: 10.1111/are.12544

Dehais, C., Eudeline, R., Berrebi, P. \& Argillier, C. (2010). Microgeographic genetic isolation in chub (Cyprinidae: Squalius cephalus) population of the Durance River: estimating fragmentation by dams. Ecology of Freshwater Fish, 19, 267-278. DOI: 10.1111/j.1600-0633.2010.00411.x.

Demirol, F., Gündüz, F., Yıldız, N., Kurtoğlu, M., Çoban, M.Z. \& Yüksel, F. 2016. Some growth parameters of chub (Squalius cephalus) living in Uzunçayır Dam Lake (Tunceli-Turkey). Journal of Limnology and Freshwater Fisheries Research, 2(2), 67-76. DOI: 10.17216/LimnoFish-5000125245

Garcia, C.B., Buarte, J. O., Sandoval, N., Von Schiller, D. \& Mello, N.P. (1989). Length-weight relationships of demersal fishes from The Gulf of Salamanca, Colombia. Fishbyte, 21, 30-32. 
Gonçalves, J.M.S., Bentes, L., Lino, P. G., Ribeiro, J., Canario, A.V.M. \& Erzini K. (1997). Weight-length relationships for selected fish species of the small-scale demersal fisheries of the south and south-west coast of Portugal. Fisheries Research, 30, 253-256. DOI: 10.1016/S0165-7836(96)00569-3

Gouskov, A. (2016). Impacts of river fragmentation on the genetic population structure of the chub (Squalius cephalus) [PhD Thesis]. ETH Zurich. 131 p.

Hossain, M.Y., Ahmed, Z. F., Leunda, PM., Jasmine, S., Oscoz, J., Miranda, R. \& Ohtomi, J. (2006). Condition, length-weight and length-length relationships of the Asian striped catfish Mystus vittatus (Bloch, 1794) (Siluriformes: Bagridae) in the Mathabhanga River, southwestern Bangladesh. Journal of Applied Ichthyology. 22, 304-307.

DOI: 10.1111/j.1439-0426.2006.00803.x

Innal, D. (2010). Growth properties of three Cyprinid species [Squalius cephalus (Linnaeus, 1758); Tinca tinca (Linnaeus, 1758) and Alburnus escherichii Steindachner, 1897] living in Camkoru Pond (Ankara-Turkey). Kafkas University Journal of Veterinary Faculty. 16 (Suppl-B), 297-304. DOI: 10.9775/kvfd.2010.2346

Kautrakis, E.T. \& Tsikliras, A.C. (2003). Length-weight relationships of fishes from three northern Aegean estuarine systems (Greece). Journal of Applied Ichthyology, 19, 258-260. DOI: 10.1046/j.1439-0426.2003.00456.x

Kara, C. \& Solak, K. (2004). Growth properties of chub (Leuciscus cephalus L 1758) in Sır Dam Lake (Kahramanmaraş). KSU Sciences and Engineering Journal, 7(2), 1-8.

Karataş, M. \& Can, M.F. (2005) Growth, mortality and yield of chub (Leuciscus cephalus L., 1758) population in Almus Dam Lake, Turkey. Journal of Biological Sciences 5(6), 729-733.

Kalkan, E., Yılmaz, M. \& Erdemli, A.U. (2005). Some bological properties of the Leucisus cephalus (L., 1758) population living in Karakaya Dam Lake in Malatya (Turkey). Turkish Journal of Veterinary and Animal Science, 29 (1), 49-58.

Kırankaya, S.G. \& Ekmekçi F.G. (2007). Variations in growth properties of chub (Squalius cephalus, L., 1758) living in Gelingüllü Dam Lake. Journal of Balıkesir University Institute of Science and Technology, 9(2), 125-134.

Kilıc, S. \& Becer, Z.A. (2016). Growth and Reproduction of Chub (Squalius cephalus) in Lake Yeniçağa, Bolu, Turkey. International Journal of Agriculture \& Biology. 18(2), 149-424. DOI: 10.17957/IJAB/15.0106

Koç, H.T., Erdogan, Z., Tinkci, M. \& Treer, T. (2007). Age, growth and reproductive characteristics of chub, Leuciscus cephalus (L., 1758) in Ikizcetepeler Dam Lake (Balikesir). Journal of Applied Ichthyology, 23, 1924. DOI: $10.1111 / j .1439-0426.2006 .00787 . x$

Laroche, J., Durand, J.D., Bouvet, Y., Guinand, B. \& Brohon, B. (1999). Genetic structure and differentiation among populations of two cyprinids, Leuciscus cephalus and Rutilus rutilus, in a large European river. Canadian Journal of Fisheries and Aquatic Science. 56, 1659-1667. DOI: $10.1139 / 999-100$
Moutopoulos, D.K. \& Stregiou, K.I. (2002). Length-weight and length-length relationships of fish species from the Aegean Sea (Greece). Journal of Applied Ichthyology, 18, 200-203.

DOI: 10.1046/j.1439-0426.2002.00281.x

Mert, R., Bulut, S. \& Solak, K. (2015). Apa Baraj Gölü'nde Yaşayan Squalius cephalus (L., 1758)'un Bazı Biyolojik Özellikleri. Afyon Kocatepe Üniversitesi Fen Ve Mühendislik Bilimleri Dergisi, 6 (2), 1-12.

Nikolsky, G.V. (1963). The Ecology of Fishes, Academic Press., London.

Özcan, E.I., Serdar, O. \& Aydın, R. (2017). Length-weight and length-length relationships of Squalius cephalus (L., 1758) in Karasu River (ErzincanErzurum). Yunus Araştırma Bülteni, 1, 109-114 DOI: 10.17693/yunusae.v17i26557.284938

Petrakis, G. \& Stergiou, K.I. (1995). Length-weight relationships for 33 fish species in Greek waters. Fisheries Research, 21, 465-469. DOI: 10.1016/0165-7836(94)00294-7

Şaşı, H. \& Balık, S. (2003). Age, growth and sex ratio of chub (Leuciscus cephalus L., 1758) in Topçam Dam Lake. Ege Journal of Fisheries and Aquatic Science, 20, 503-515. DOI: 10.12714/egejfas.2003.20.3.5000157106

Şaşı, H. \& Özay, G.G. (2017). Age, growth, length-weight relationship and reproduction of chub, Squalius cephalus (L., 1758) in upper Akcay River, Turkey. Pakistan Journal of Zoology, 49 (5), 1571-1580. DOI: 10.17582/journal.pjz/2017.49.5.1571.1580

Singh, M. \& Serajuddin, M. (2017). Length-weight, length- length relationship and condition factor of Channa punctatus collected from three different rivers of India. Journal of Entomology and Zoology Studies, 5 (1), 191-197.

Sedaghat, S., Ahangari, W.D.P., Arabi, M.H., Rahmani, H. \& Vatandoust, S. (2012). Age and Growth of Chub, Squalius cephalus (Bonaparte, 1837), in Gamasiab River of the Hamadan Province, Iran. World Journal of Fish and Marine Sciences, 4(6), 550-553. DOI: 10.5829/idosi.wjfms.2012.04.06.64171

Stefanova, E., Uzunova, E., Hubenova, T., Vasileva, P., Terziyski, D. \& lliev, I. (2008). Age and growth of the chub Leuciscus cephalus L., from the Maritz River (South Bulgaria). Bulgarian Journal of Agricultural Science, 14(2), 214-220

Turan, D., Tomovic, L. \& Peši, V. (2007). Morphological variation in a common Turkish cyprinid, Squalius cephalus, across Turkish water catchment areas. Journal of Zoology in the Middle East. 40(1), 63-70. DOI: 10.1080/09397140.2007.10638205

Ünver, B. \& Kekilli, S. (2010). Growth properties of chub (Squalius cephalus L., 1758 ) in the Hafik Lake (Sivas). Eğirdir Su Ürünleri Fakültesi Dergisi, 6: 1 20-28

Ünver, B. \& Erk'akan, F. (2012). Population characteristics of Squalius cephalus in Lake Tödürge (Sivas). Ege Journal of Fisheries and Aquatic Science, 29, 95-100. DOI: 10.12714/egejfas.2012.29.2.5000156440

Zar, J.H. (1999). Biostatistical analysis. New Jersey, Prentice-Hall. 